\title{
Rola edukacji regionalnej w pielęgnowaniu pamięci przeszłości - na przykładzie wielokulturowego Białegostoku
}

Streszczenie: W tekście podejmuję próbę ukazania znaczenia edukacji regionalnej w pielęgnowaniu pamięci przeszłości, odnosząc się do sytuacji wielokulturowego Białegostoku. Zastanawiam się nad rolą, jaką pełnią badania dotyczące pamięci przeszłości w planowaniu i realizowaniu działań edukacyjnych i wychowawczych. Zwracam uwagę na wybrane kwestie związane z pamięcią przeszłości w kontekście badań społecznych.

Słowa kluczowe: edukacja międzykulturowa, edukacja regionalna, pamięć przeszłości, tożsamość zbiorowa, tożsamość indywidualna, dziedzictwo kulturowe, region, regionalizm.

Ludzie sami tworza swoją historie, ale nie tworza jej dowolnie, nie $w$ wybranych przez siebie okolicznościach, lecz $w$ takich, jakie zostaly im dane i przekazane. Tradycja wszystkich zmarlych pokoleń ciąży na umysłach żyjących ${ }^{1}$.

W przygotowanym tekście podejmuję próbę pokazania znaczenia edukacji regionalnej w pielęgnowaniu pamięci przeszłości, odnosząc się do sytuacji wielokulturowego Białegostoku. Zastanawiam się nad rolą, jaką pełnią badania dotyczące pamięci przeszłości w planowaniu i realizowaniu działań edukacyjnych i wychowawczych. Zwracam uwagę na wybrane kwestie związane z pamięcią przeszłości w kontekście badań społecznych.

Inspiracją do poznania i analizy problemu dotyczącego pamięci przeszłości przedwojennego wielokulturowego Białegostoku² były studia literatury

1 K. Marks, F. Engels: Dzieta wybrane. T. 1. Warszawa 1949, „Książka i Wiedza”, s. 229.

2 Mówiąc o przedwojennym Białymstoku, mam na myśli Białystok z okresu II Rzeczypospolitej. 
i analizy badań naukowych ukazujące rolę edukacji międzykulturowej i regionalnej w budowaniu postaw otwartości wobec odmienności kulturowej, kształtowania tożsamości kulturowej, a także zagadnień i wątków związanych z edukacją międzykulturową i regionalną, takich jak: tożsamość zbiorowa, dziedzictwo kulturowe, pamięć przeszłości, region, regionalizm. Ponadto impulsem do podjęcia tego tematu były osobiste refleksje dotyczące przekazywania znaczenia pamięci przeszłości i jej roli w kształtowaniu tożsamości jednostek i grup oraz jej wpływu na tożsamość miejsca - tożsamość regionu.

Fenomenem pamięci przeszłości zajmują się przedstawiciele różnych nauk społecznych. Warto pamiętać, że termin „pamięć”, podobnie jak inne pojęcia określające złożone procesy, zagrożony jest reifikacją, czyli „urzeczowianiem”. W tym przypadku problem, który pojawia się w związku z reifikacją zwany jest „mijaniem się”. Oznacza to, że tę samą nazwę wykorzystuje się do określenia odmiennych zjawisk, jednocześnie mówi się o podobnej problematyce, używając odmiennych pojęć: pamięć przeszłości, pamięć zbiorowa, pamięć społeczna, pamięć historyczna, świadomość historyczna ${ }^{3}$.

Mając świadomość wyżej zasygnalizowanego zagrożenia, na potrzeby tejże pracy mówiąc o pamięci przeszłości, mam na myśli pamięć społeczną w znaczeniu zaproponowanym przez Andrzeja Szpocińskiego ${ }^{4}$. Autor podkreśla, że na pamięć społeczną składa się to, co pozostaje z przeszłości w przeżyciach członków grupy lub to, co czynią swoją przeszłością. Jest to zbiór wspomnień o zdarzeniach rzeczywistych lub zmyślonych, zdarzeniach przeżytych bezpośrednio lub takich, o których wiedza przekazywana jest $\mathrm{z}$ pokolenia na pokolenie w tradycji ustnej, pisanej oraz za pośrednictwem kanałów informacyjnych. Ważne jest to, że w pamięci społecznej oceny zdarzeń przeszłych odnoszą się do tego, co było kiedyś, ale też do tego, co dzieje się dziś i dziać się będzie w przyszłości. Oceny zdarzeń przeszłych umieszczone są w czasie mitycznym, co sprawia, że nadal mają żywy charakter. Pamięci społecznych jest wiele - tyle, ile grup, które budują swoją tożsamość, odwołując się do przeszłości. Nie ma więc jednej „właściwej” pamięci społecznej, w przeciwieństwie do pamięci historycznej, która wymaga posługiwania się „poprawną” wiedzą o przeszłości. Pamięć historyczna jest

3 Więcej na ten temat: B. Szacka: Pamięć zbiorowa. W: A. Szpociński (red.): Wobec przeszłości, pamięć przeszłości jako element kultury współczesnej. Warszawa 2005, Instytut im. Adama Mickiewicza.

4 A. Szpociński, P. T. Kwiatkowski: Przeszłość jako przedmiot przekazu. Warszawa 2006, PAN, „Scholar”, s. 27. 
ważnym kontekstem pamięci społecznej, chociaż wyraźnie różni się od niej pod względem funkcjonalnym, strukturalnym oraz poznawczym ${ }^{5}$. Pamięć przeszłości jest rezultatem wpływów czynników społecznych na pamięć indywidualną. Opowiedzenie się za takim rozumieniem pamięci społecznej odwołuje do prekursora badań na temat pamięci zbiorowej - Maurice'a Halbwachsa ${ }^{6}$. Tezą jego prac jest społeczne uwarunkowanie pamięci, to znaczy, że bez społecznych ram odniesienia pamięć indywidualna nie mogłaby powstać ani manifestować swojej obecności. Jan Assmann w odniesieniu do tej tezy dopowiada, że: „[...] jednostka dojrzewająca w zupełnej samotności nie posiadałaby pamięci. Pamięć rozwija się w człowieku wraz z procesem jego socjalizacji. Co prawda tylko jednostki »mają " pamięć, ale jest ona kształtowana przez zbiorowość”.

Pamięć członków zbiorowości jest kształtowana przez społeczeństwo, w którym jednostki żyją. Wspomnienia indywidualne powstają i trwają w procesie komunikacji i interakcji w ramach grup społecznych: „Pamiętamy nie tylko to, czego dowiedzieliśmy się od innych, lecz także to, co inni nam opowiedzieli i co uznają za znaczące i jako takie przekazują. Przede wszystkim całość doświadczeń odbywa się w kontekście społecznych ram znaczeniowych"8. Innymi słowy podmiotem pamięci przeszłości i pamiętania jest jednostka, która jest zdeterminowana „ramami” społecznymi, organizującymi pamięć. M. Halbwachs definiuje pamięć, ale też odnosi się do kategorii zapominania. Parafrazując słowa Halbwachsa, Jan Assmann zauważa: „Jeżeli człowiek - i społeczeństwo - są w stanie pamiętać jedynie to, co pozostaje rekonstruowalne jako przeszłość w ramach odniesień właściwych dla określonej teraźniejszości, zapominane zostaje właśnie to, co w teraźniej-

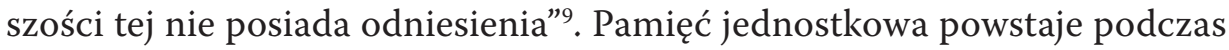
udziału w procesach komunikacyjnych, w trakcie udziału w różnych grupach społecznych, poczynając od rodziny przez grupy rówieśnicze, religijne, narodowe, aż po globalne wspólnoty. Pamięć powstaje i trwa dzięki wymianie znaczeń w trakcie kontaktów interpersonalnych, gdy komunikacja zostaje

5 Tamże, s. 18-24.

6 Więcej na temat społecznych ram pamięci: M. Halbwachs: Społeczne ramy pamięci. Warszawa 2008, PWN.

7 J. Assmann: Pamięć kulturowa. Pismo, zapamiętywanie i polityczna tożsamość w cywilizacjach starożytnych. Warszawa 2008, UW, s. 51.

8 Tamże, s. 52.

9 Tamże. 
osłabiona lub znikają ramy odniesienia następuje zapominanie. Pamięć jednostkowa jest konstruktem powstałym dzięki czerpaniu z zasobów pamięci zbiorowej. Pamięć przeszłości jest zatem ważnym elementem kształtującym tożsamość zbiorową.

Kontekstem teoretycznym tekstu jest edukacja regionalna definiowana jako jedna z dyscyplin pedagogiki, gdzie wyraźnie podkreśla się, że zrozumienie problemów pojawiających się współcześnie na danym obszarze wymaga poznania wcześniejszych dziejów tego regionu. Obserwuje się tu wyraźny związek między przeszłością, teraźniejszością i projektowaną przyszłością. Umiejscowienie pamięci przeszłości w teraźniejszości wynika z kulturowego uwarunkowania pojęcia przeszłości. Kulturę, w której żyjemy wyróżnia linearne poczucie czasu. W przeciwieństwie do kultur, w których dominuje mityczne poczucie czasu, w naszej kulturze wyraźnie odczuwa się zależność trzech wymiarów: wpływu przeszłości na teraźniejszość oraz obecnych na przyszłość. Jest to istotne w badaniu procesów kształtowania się tożsamości - mającej charakter interpersonalny i społeczny - kształtowanej i poddawanej wpływom zależnym od rodzajów i jakości relacji jednostki z innymi. Tożsamość jest procesem dynamicznym i jest weryfikowana w teraźniejszości poprzez odniesienia do przeszłości, oraz przewidywania siebie w przyszłości. Innymi słowy, im szerzej odpowiemy sobie na pytanie "skąd pochodzimy” tym łatwiej i pełniej zilustrujemy to, „kim jesteśmy”, a to pozwoli precyzyjniej przewidzieć i zdefiniować, „dokąd zmierzamy”.

Opowiadając się za terminem „pamięć przeszłości”, wyraźnie chcę podkreślić jej związek z teraźniejszością. Jak pisze A. Szpociński, „przeszłość i teraźniejszość jako fenomeny będące przedmiotem percepcji konkretnych jednostek powiązane są wielorakimi nićmi zależności. Pamięć przeszłości powinna być pojmowana jako element konkretnych, istniejących w określonym czasie i przestrzeni kultur. Sam fenomen pamięci przeszłości, jakkolwiek przedmiotem jego odniesienia jest to, co zdarzyło się kiedyś, należy do teraźniejszości danej kultury, nie do jej przeszłości” ${ }^{10}$. Zatem misja edukacji regionalnej w zakresie pielęgnowania pamięci przeszłości danego regionu jest bezsporna. Podobnie jak kluczowa jest jej rola w generowaniu sytuacji inspirujących do świadomych poszukiwań tożsamościowych, bowiem, jak pisze A. Szpociński, „budzenie się zainteresowań regionami i subregionami

10 A. Szpociński: Pamięć przeszłości jako element kultury wspótczesnej. W: A. Szpociński (red.): Wobec przesztości, pamięć przeszłości jako element kultury wspótczesnej. cyt. wyd., s. 5. 
oraz ich przeszłością jest konsekwencją rosnących zainteresowań historiami rodzinnymi, co z kolei wiąże się z ogólnymi zmianami postaw wobec przeszłości"11.

Szukając odpowiedzi na pytanie: Jaka jest pamięć przeszłości Białegostoku w świadomości jego mieszkańców?, nie można pominąć kontekstu, który kształtuje pamięć i równocześnie jest przez nią kształtowany. W przypadku Białegostoku kontekstem pamięci przeszłości był i nadal jest wielokulturowy charakter miasta. Białystok jest szczególnym regionem w sensie historyczno-kulturowym. Mówiąc o regionie historycznym, mam na myśli znaczenie zaproponowane przez J. Topolskiego, czyli „pewną całość wyraźnie wyodrębnioną dziejami, [...] pewien układ gospodarczy, społeczny, polityczno-administracyjny, kulturalny i psychiczny [...] dający się wyodrębnić z szerszej tkanki historycznej” ${ }^{12}$. Natomiast myśląc o regionie w sensie kulturowym, odnoszę się do propozycji Jerzego Nikitorowicza opisującego region kulturowy jako „obszar, na którym wyodrębniły się określone cechy, a jego mieszkańcy posiadają świadomość zwyczajów i systemu wartości oraz poczucie własnej tożsamości. Ujmowany jest przedmiotowo, jako region administracyjny, wyodrębniony w danym państwie, oraz podmiotowo, jako region wirtualny, wyodrębniony w następstwie działań różnych podmiotów świadomie dążących do jego rozwoju"13. Tereny obecnego Białegostoku od wielu wieków miały charakter pograniczny ${ }^{14}$. Odnotowuje się, że około pierwszej połowy I tysiąclecia nowej ery obecne białostockie już wówczas usytuowane było w pasie przejściowym, podlegając wpływom Bałtów oraz plemion letto-litewskich i z Mazowsza Mławskiego. Walki o podporządkowanie sobie terenów puszczańskich między Narwią i Biebrzą a Bugiem długo nie ustawały. Jak głosi legenda około roku 1323-1324 książę Giedymin, polując w Puszczy Bielskiej, zapuścił się na jej północno-zachodni skraj, w pobliże granicy z Mazowszem. Odpoczywając nad strumieniem, zachwycił się jego przejrzystością, nazwał

11 A. Szpociński, P. T. Kwiatkowski: Przeszłość jako przedmiot przekazu. cyt. wyd., s. 58.

12 P. Petrykowski: Edukacja regionalna. Problemy podstawowe i otwarte. Toruń 2003, UMK, s. 76-77. Zobacz również: J. Topolski: Założenia metodologiczne badań regionalnych w zakresie historii. „Dzieje Najnowsze” 1973, nr 2, s. 23.

13 J. Nikitorowicz: Edukacja regionalna i międzykulturowa. Warszawa 2009, WAiP, s. 513.

14 Więcej na ten temat: A. Dobroński: Białystok - historia miasta. Białystok 2001, Zarząd Miasta Białegostoku, s. 8 i n. 
to miejsce białym stokiem. Postanowił założyć tu dwór oraz wieś o nazwie Biały Stok. Białystok od samego początku kształtował się jako miasto pograniczne podlegające wpływom różnych kultur, religii, wyznań i nacji. Krzyżowały się tu z sobą wpływy zachodu i wschodu, Rzymu i Bizancjum. Duży wpływ na rozwój miasta Białegostoku w XVI i XVII wieku mieli Wiesiołowscy, a w szczególności Piotr Wiesiołowski Młodszy - określany mianem pierwszego wielkiego dobrodzieja białostockiego. Białystok został przez nich przekształcony w miasteczko prywatne, które zostało centrum ich dóbr, ale też zostało ośrodkiem oddziałującym na dalsze okolice, między innymi przez stworzenie tkackiej manufaktury. Przez wiele lat utrzymywano, że o Białymstoku jako mieście można mówić dopiero od momentu wystawienia przywileju przez Augusta III w dniu 1 lutego 1749 roku. W ostatnich latach wraz ze wzrostem pośrednich dowodów przyjmuje się rok 1692 jako datę, od której mówi się o mieście Białymstoku ${ }^{15}$. Od 1660 roku Białystok przeszedł w ręce Aleksandry, córki Stefana Czarneckiego, żony marszałka nadwornego Jana Klemensa Branickiego z rodu Gryfitów. Jan Klemens Branicki uważany jest za twórcę wielkiego Białegostoku. Z wielkim powodzeniem kontynuował i rozwijał budowę białostockiej siedziby do roku 1771 - kiedy zmarł bezpotomnie w swoim białostockim pałacu. Myśląc o rozbudowie Białegostoku, sprowadził do niego pokaźną liczbę ludności żydowskiej oraz mieszczan z innych ośrodków (rzemieślników wiejskich i dworskich). Pierwsze wzmianki o Żydach na terenach białostockich pochodzą z 1658 roku. Liczba mieszkańców Białegostoku u schyłku życia hetmana Branickiego wynosiła 545 osób czynnych zawodowo, w tym 344 chrześcijan i 201 Żydów. Po śmierci Jana Klemensa Branickiego pałac, miasto i część okolicznych włości utrzymała jego trzecia żona Izabela (Elżbieta) Branicka z Poniatowskich. Od styczna 1796 roku rządy w Białymstoku przejęli Prusacy, którzy tu właśnie ustalili stolicę rozległego departamentu w prowincji Prus Nowowschodnich ${ }^{16}$. W pierwszych latach XIX wieku Cesarstwo Rosyjskie zaczęło stopniowo przejmować władzę nad obwodem białostockim, gdzie ostateczną zwierzchność Rosji utrzymano na Kongresie Wiedeńskim w 1815 roku ${ }^{17}$. Rosjanie ustanowili w Białymstoku samorząd wybierany na trzy lata, wprowadzili reformatorską zasadę, że połowa rady miejskiej i magistratu (sądu) miała być religii mojże-

15 Tamże, s. 21 i n.

16 Więcej na ten temat: A. Dobroński: Białystok - historia miasta. cyt. wyd., s. 53 i n.

17 Tamże, s. 58 i n. 
szowej. Stan społeczeństwa białostockiego w momencie przejmowania władzy przez carskie Imperium w 1807 roku, jak pisze Adam Dobroński, wynosił 4145 osób, w tym 2116 Żydów i 2029 chrześcijan ${ }^{18}$. Natomiast dane, na które powołuje się Andrzej Sadowski wskazują, że liczba mieszkańców Białegostoku w tym czasie wynosiła 6 tysięcy, w tym około 4 tysięcy Żydów ${ }^{19}$. Wśród białostoczan w latach 1857-1895 zdecydowanie przeważali Żydzi, odsetek osób religii mojżeszowej zwiększył się od 69\% do 78\% ogółu mieszkańców, natomiast Polacy stanowili 22\%. Pod koniec XIX wieku odsetek katolików obniżył się z 22\% do 9,9\% ${ }^{20}$. Dobroński w odniesieniu do Białegostoku z tego okresu pisze, „Białystok nabierał nadal stopniowo cech obcych, typowych dla większych ośrodków pogranicza wschodniego, coraz bardziej odmiennych od miast z okresu staropolskiego"21. Sadowski określa Białystok w okresie od początku XIX wieku do rozpoczęcia I wojny światowej mianem miasta żydowsko-polskiego, bowiem w tym czasie liczba mieszkańców pochodzenia żydowskiego znacznie przekraczała połowę jego mieszkańców. Sytuacja religijno-etniczna białostoczan w okresie II Rzeczypospolitej zmieniła się między innymi na skutek przesunięcia granicy na wschód, licznych migracji z terenów centralnej Polski, co spowodowało wzrost ludności polskiej. Według Pierwszego Spisu Ludności RP z 30 listopada 1921 roku ${ }^{22}$ Białystok liczył 76792 obywateli, w tym 48,7\% Żydów, 46,6\% Polaków, 1,9\% Niemców, 8\% Rosjan, 0,8\% Białorusinów, 0,2\% Innych. Przy czym trzeba pamiętać, że wówczas Polakami czuło się wielu wyznawców prawosławia oraz judaizmu.

Na podstawie przedstawionych w dużym skrócie kolei losów kształtowania się miasta Białegostoku wyraźnie można zobaczyć, że od początku jego tereny miały charakter stykowo-przejściowy. Był to obszar, na którym spotykali się przedstawiciele różnych kultur. Znaczący wkład w budowę miasta mieli Polacy, Żydzi, Niemcy, Rosjanie, Białorusini, Litwini, Tatarzy. Wielokulturowy charakter Białegostoku zachował się do dnia dzisiejszego. Chociaż wizerunek miasta - zróżnicowanego etnicznie - na przestrzeni dziejów ulegał licznym przeobrażeniom. Powodów było wiele, między innymi zna-

18 Tamże, s. 63.

19 A. Sadowski: Białystok. Kapitał społeczny mieszkańców miasta. Białystok 2006, WSE, s. 156.

20 Tamże, s. 156.

21 A. Dobroński: Białystok - historia miasta. cyt. wyd., s. 75.

22 Tamże, s. 157. Zobacz również: Województwo białostockie. Warszawa 1927, GUS. Pierwszy Spis Ludności RP z 30 listopada $1921 \mathrm{r}$. 
czący wpływ miały liczne migracje, zmiany granic miasta i województwa białostockiego na przestrzeni dziejów, rosnąca świadomość narodowa oraz procesy asymilacyjne. Największe jednak znaczenie miała II wojna światowa, która nieodwracalnie zmieniła obraz miasta $\mathrm{z}$ heterogenicznego na miasto o homogenicznym wizerunku. Dopiero po roku 1980 zauważa się wyraźne zmiany struktury etniczno-kulturowej Białymstoku. Przedstawiciele różnych grup kulturowych zaczęli otwarcie wyrażać swoje postawy narodowe i religijne i stopniowo ujawniały się kolejne mniejszości narodowe. Wyraźnie zaakcentowały swoją obecność mniejszość białoruska, zinstytucjonalizowana w mieście od 1956 roku, mniejszość litewska, ukraińska, romska, tatarska oraz mniejszość rosyjska ${ }^{23}$.

Zakładam, że istotną rolę $\mathrm{w}$ pielęgnowaniu pamięci przeszłości, szczególnie w wielokulturowym społeczeństwie, obok edukacji międzykulturowej odgrywa edukacja regionalna, w której podkreślane jest, „że [...] dydaktyczne znaczenie lokalnego dziedzictwa kulturowego, jako niezbędnego elementu tożsamości jednostkowej i społecznej, stanowi ważny składnik procesu integracji europejskiej, sprzyja zakorzenieniu w tzw. małej ojczyźnie"24. Z perspektywy niniejszych analiz ważnym kontekstem pamięci przeszłości Białegostoku jest przeszłość regionalna ${ }^{25}$, którą rozumiem jako sumę faktów, które zdarzyły się na terytorium zwanym regionem, a której podmiotem była cała zamieszkująca go zbiorowość - wchodzące w jej skład mniejsze grupy lub należące do niej jednostki. Na przeszłość regionu składają się liczne przeszłości różnych grup społecznych, niezależnie od siebie symbolizowane, pamiętane, dyskutowane. Przeszłość ważnej mniejszej grupy może być włączona do tradycji regionalnej na dwa sposoby. Po pierwsze, dzieje tejże grupy mogą wchodzić do tradycji regionalnej jako całość, to znaczy całemu okresowi istnienia tej grupy przypisuje się określoną wartość, ważną dla całej zbiorowości. Drugim sposobem jest dopełnianie obrazu przeszłości regionalnej wybranymi faktami z dziejów ważnej grupy mniejszościowej. Edukacja regionalna ma istotne zadanie w zakresie uświadamiania potencjału, jakim dysponuje wielokulturowe społeczeństwo w zakresie uwrażli-

23 A. Sadowski: Białystok. Kapitat społeczny mieszkańców miasta. cyt. wyd., s. 162.

24 B. Milerski, B. Śliwerski (red.): Leksykon PWN. Pedagogika. Warszawa 2000, PWN, s. 56.

25 A. Szpociński, P. T. Kwiatkowski: Przeszłość jako przedmiot przekazu. cyt. wyd., s. $82-83$. 
wiania na odmienność różnych grup kulturowych zamieszkujących od wielu stuleci to samo terytorium, w tym przypadku tereny Białegostoku. Edukacja regionalna dysponuje strategią umożliwiającą konstruktywne spotkanie się kilku różnych grup kulturowych, któremu przyświecać może dobro wspólnego miejsca. Zwłaszcza, gdy ma się na uwadze fakt, że wszyscy członkowie białostockich autochtonicznych grup etnicznych w Białymstoku czują się „u siebie”.

Przyjmuję za Nikitorowiczem, że edukacja regionalna jest edukacją środowiskową i jako taka ma szczególne znaczenie w pielęgnowaniu pamięci przeszłości danego regionu, „[...] są to wszelkie działania przekazujące wiedzę o »ojczyźnie prywatnej« i kształtujące więzi z nią, ze światem pierwotnego zakorzenienia. Wychodzi naprzeciw człowiekowi, kształtując umiejętność współżycia, współdziałania i ustawicznego zaangażowania »w małej ojczyźnie«, jednocześnie zapewnia ciągłość kulturową grupy poprzez wyposażanie w wiedzę, uwrażliwianie na wartości uniwersalne na bazie więzi lokalnych. Treści edukacji regionalnej związane są z krajobrazem, architekturą, zabytkami kultury duchowej i materialnej, gwarą (dialektem miejscowym), folklorem, legendami, sztuką ludową, historią, z lokalnymi bohaterami (osobami znaczącymi) i wydarzeniami, kontaktami międzyludzkimi, przekazem międzypokoleniowym, obyczajowością społeczności, obcowaniem z przyrodą itp." ${ }^{26}$.

Piotr Petrykowski, analizując dokumenty MENiS, wskazuje na rolę edukacji regionalnej w rekonstruowaniu przeszłości konkretnego regionu w ramach odniesień istotnych dla teraźniejszości, pisząc, że edukacja regionalna jest to: „[...] umożliwianie młodym ludziom poznawania własnego dziedzictwa kulturowego, tradycji regionalnej, uwewnętrznienia wartości i treści regionalnych, tym samym więc kształtowanie i utrwalanie postaw regionalnych ${ }^{27 "}$. Edukacja regionalna jest ściśle powiązana z edukacją międzykulturową, jest w pewnym sensie jej pierwszym etapem, niezbędnym warunkiem powodzenia zamierzeń wynikających z teoretycznych założeń edukacji międzykulturowej. Wskazują na to słowa Mirosława Sobeckiego: „Przez edukację międzykulturową należy rozumieć wszystkie te oddziaływania, które dotyczą kultur i ich elementów, będących w stanie interakcji (dyfuzji bądź interferencji) oraz zmierzają do takiego kreowania aktów pedagogicznych,

26 J. Nikitorowicz: Edukacja regionalna i międzykulturowa. cyt. wyd., s. 502.

27 P. Petrykowski: Edukacja regionalna. Problemy podstawowe i otwarte. cyt. wyd., s. 50 . 
że ich efektem jest powstawanie właściwych postaw jednostek i grup wobec odmienności kulturowej oraz świadome, refleksyjne zakorzenienie we własnym dziedzictwie kulturowym" 28 .

Istota edukacji regionalnej w pielęgnowaniu pamięci przeszłości jest również wyraźna w kontekście problemu dziedzictwa kulturowego. Bowiem pamięć przeszłości warunkuje przekaz elementów kultury regionu, nadając tym samym znaczenie dziedzictwu kulturowemu, które, jak pokazuje Piotr Petrykowski, „[...] w kontekście rozważań nad czynnikami konstytuującymi tożsamość kulturową i tożsamość regionalną jest składową wyznaczników regionu"29. Badania nad pamięcią przeszłości pozwalają zatem prześledzić znaczenie dziedzictwa kulturowego dla współczesnych, młodych pokoleń. Analizy tego problemu mogą być pomocne w konstruowaniu działań edukacyjnych i wychowawczych na rzecz wykorzystywania potencjału regionu. Zabiegi te są potrzebne między innymi po to, by uniknąć dramatu, przed którym przestrzega Henryka Kwiatkowska, pisząc, że „[...] człowiek, który w swej pamięci nie ma miejsc, do których chętnie wraca, chociażby myślą, jest na swój sposób pozbawiony więzi z innymi ludźmi, jest w gruncie rzeczy samotny"30.

Analiza pamięci przeszłości danego regionu w świadomości jego mieszkańców pozwala na wyodrębnienie znaków mających istotną wartość w budowaniu wewnątrzgrupowych interakcji oraz ważnych znaków z punktu widzenia kształtowania się tożsamości zbiorowej. Pojęcia znak używam w znaczeniu zaproponowanym przez Rolanda Barthesa ${ }^{31}$. Barthesa interesowały pozornie oczywiste znaki, które komunikują ideologiczne lub konotatywne znaczenia i utrwalają dominujące wartości społeczeństwa. Początkowo Barthes opisywał teorię semiotyczną jako próbę wyjaśnienia „mitu”. Później wprowadził termin konotacja dla określenia bagażu ideologicznego, którego znaki wszędzie ze sobą niosą. Autor wyraźnie podkreśla, że znak jest kom-

28 M. Sobecki: Kultura symboliczna a tożsamość. Studium tożsamości kulturowej Polaków na Grodzieńszczyźnie z perspektywy edukacji międzykulturowej. Białystok 2007, „Trans Humana”, s. 27.

29 P. Petrykowski: Edukacja regionalna. Problemy podstawowe i otwarte. cyt. wyd., S. 128.

30 H. Kwiatkowska: Czas, miejsce, przestrzeń - zaniedbane kategorie pedagogiczne. W: A. Nalaskowski, K. Rubacha (red.): Pedagogika u progu trzeciego tysiąclecia. Toruń 2001, UMK, s. 41.

31 R. Barthes: Mitologie. Warszawa 2008, „Aletheia”. 
binacją znaczącego (signifiant) i znaczonego (signifié), „[...] każda semiologia zakłada stosunek pomiędzy dwoma terminami: signifiant i signifié. Ten stosunek dotyczy dwóch porządków i dlatego nie jest równością, ale ekwiwalencją. [...] w każdym systemie semiologicznym mamy do czynienia nie z dwoma, ale z trzema różnymi terminami; nie ogarniamy bowiem wcale jednego terminu po drugim, ale łączącą je korelację: istnieje zatem signifiant, signifié i znak, który jest asocjacyjną całością dwóch pierwszych terminów"32. Opis znaku Barthesa jako korelacji między częścią znaczącą i znaczoną wywodzi się bezpośrednio z koncepcji de Saussure'a. De Saussure - szwajcarski językoznawca zilustrował znak jako kartkę papieru zapisaną z obu stron - część znacząca jest po jednej stronie, część znaczona po drugiej. Odcięcie kawałka $\mathrm{z}$ jednej strony automatycznie tak samo zmniejsza drugą stronę. Każdy znak - w tym przypadku znakiem jest pamięć przeszłości - składa się z nośników znaczeń, czyli elementów znaczących i powiązanych z nimi elementów znaczonych. Barthes twierdzi, że każdy znak ideologiczny jest rezultatem dwóch połączonych ze sobą systemów znaków. Pierwszy jest ściśle opisowy - obraz znaczącego elementu i znaczone pojęcie łączą się, by stworzyć denotowany znak. W odniesieniu do pamięci przeszłości elementami znaczącymi są obrazy faktów historycznych i postaci, wokół których koncentruje się społeczna debata. Natomiast elementy znaczone są to pojęcia faktów i postaci, które w przekonaniu członków grupy są ważne, bowiem wyrażają istotne treści, wzory myślenia, zachowania, wartości.

Parafrazując słowa Andrzeja Szpocińskiego, można powiedzieć, że pamięć zbiorowa jest tym, co pozostaje z przeszłości w przeżyciach członków grupy lub tym, co czynią swoją przeszłością ${ }^{33}$. To, co należeć będzie do obszaru pamięci przeszłości kultury - w sensie semiologicznym - jest zmienne, zależy od zakresu potrzeb uczestnictwa w przyjmowanej kulturze, możliwości rozumienia kanonu kulturowego oraz kompetencji kulturowych poszczególnych osób i grup. Ponadto obszar pamięci przeszłości warunkowany jest decyzjami członków grup na temat tego, co chcą przekazać kolejnym pokoleniom, ale też tego, co następcy zdecydują się zachować w swojej pamięci po przodkach lub wcześniejszych gospodarzach miejsc, które współcześnie zamieszkują. Jak mówi Petrykowski, „Kryteria uznawania wielu wytworów za

2 Tamże, s. 243.

33 A. Szpociński, P. T. Kwiatkowski: Przeszłość jako przedmiot przekazu. cyt. wyd., s. 27 . 
składowe dziedzictwa kulturowego ulegają i ulegać muszą ciągłym zmianom, włączając weń te elementy, które są pokoleniu dorosłych obce lub przez nich nieakceptowane. Te wytwory bowiem są dla młodego pokolenia pozostałością lub spadkiem po ich przodkach, z drugiej strony w ich ramach kształtuje się osobiste odczuwanie granic ojczyzn prywatnych" ${ }^{34}$.

Pielęgnowanie dziedzictwa regionu nie może mieć miejsca bez przekazu pamięci przeszłości w drodze wychowania i edukacji. Pamięć przeszłości reguluje i aktualizuje „regionalną świadomość społeczną” - którą określa się mianem regionalizmu. Przyjmuję za Petrykowskim, że zarówno dziedzictwo kulturowe, jak i pamięć przeszłości muszą być w każdej swojej postaci przewartościowane i przystosowane do zmieniających się warunków, bowiem dziedzictwo kulturowe „nie może być tradycjonalizmem, który uważa mechanicznie za dobre wszystko to, co jest zakorzenione w przeszłości" ${ }^{35}$. Badania nad pamięcią przeszłości są potrzebne po to, by społeczności regionalne mogły bez lęku o utratę tożsamości otwierać się na nowości i zapożyczenia, które warto wprowadzać tak, by korespondowały i nawiązywały do dziedzictwa poprzednich pokoleń. Badania nad pamięcią przeszłości dostarczają budulca do konstruowania obrazu własnej grupy (tożsamości grupowej). W myśl idei edukacji międzykulturowej i korespondującej z nią pamięci monumentalnej ${ }^{36}$, gdzie zdarzenia i postaci z przeszłości funkcjonują jako symbole zbiorowej identyfikacji oraz jako nośniki wzorów zachowań konstytuujących obraz zbiorowego "ja” mieszkańców danego regionu, poznajemy przeszłość, bowiem chcemy objaśnić tu i teraz istniejącą rzeczywistość, objaśnić lub odrzucić istniejące, uznane w tej rzeczywistości systemy wartości. Pamięć monumentalna dostarcza budulca do konstruowania obrazu własnej grupy, posiada jawne odniesienia do współczesności. Analiza wyników eksploracji, w tym odniesień badanych ludzi do zdarzeń z przeszłości, ujawnianie stosunku do przeszłych zdarzeń, postaci, wytworów kultury może wspierać budowę mapy pamięci przeszłości konkretnego regionu oraz pracę edukacyjną na rzecz konstruowania pamięci społecznej i budzenia świadomości tożsamości zbiorowej.

34 P. Petrykowski: Edukacja regionalna. Problemy podstawowe i otwarte. cyt. wyd., s. 132.

35 Tamże, s. 129.

36 A. Szpociński, P. T. Kwiatkowski: Przeszłość jako przedmiot przekazu. cyt. wyd., s. $29-30$. 
Szpociński wyznaczył trzy płaszczyzny ekspresji pamięci społecznej ${ }^{37}$ : płaszczyznę funkcjonalną - tu pamięć społeczna jest budulcem konstruowania tożsamości zbiorowej; płaszczyznę strukturalną - gdzie funkcjonowanie pamięci zakłada cykliczność i/lub mityczność czasu, umieszczenie zdarzeń w czasie mitycznym sprawia, że są one nadal żywe. Oceny zdarzeń odnoszą się do tego, co było kiedyś, ale też do tego, co dzieje się dziś i dziać się będzie w przyszłości. W płaszczyźnie poznawczej pamięć społeczna jest świadectwem ekspresji grupowych interesów i wartości. Tu badania nad pamięcią przeszłości ogniskują się wokół zdarzeń i postaci z przeszłości, które funkcjonują jako symbole zbiorowej identyfikacji, nośniki wartości, nośniki wzorów zachowań konstytuujących obraz zbiorowego „ja” mieszkańców danego regionu. Badania nad pamięcią przeszłości w odniesieniu do założeń edukacji międzykulturowej i edukacji regionalnej jako dziedzin w pedagogice wspierają ją w działaniach na rzecz kształtowania umiejętności współżycia, współdziałania i zaangażowania na rzecz działań w wielokulturowym świecie. Świadomość przeszłości własnej kultury otwiera na dziedzictwo kulturowe innych grup zamieszkujących w przeszłości i współcześnie ten sam region. W myśl zasady przewidującej, że poznanie, świadomość siebie, swoich korzeni i przeszłości regionu (innymi słowy swojej „małej ojczyzny”) umożliwia poznawanie innych ludzi i innych kultur, bez zagrożenia własnej tożsamości, gdzie wpływy globalne traktuje się jako inspirujące i wzbogacające kulturę regionu i pamięć o tej kulturze.

Przyjmując takie rozumienie pamięci przeszłości, założyłam, że oprócz literatury ważnym źródłem informacji na temat przeszłości miejsca są jego mieszkańcy. W przypadku Białegostoku są to białostoczanie urodzeni tu przed wojną, a których źródłem pamięci przeszłości przedwojennego Białegostoku jest ich własne doświadczenie. Szczególnie ważne wydaje się dotarcie do przedwojennych białostoczan pochodzenia żydowskiego, bowiem choć zniknęli z przestrzeni miasta, to ślady po ich autochtonicznej bytności są nadal bardzo wyraźne. Równie istotne jest zdiagnozowanie pamięci przeszłości miejsca w świadomości jego obecnych, młodych mieszkańców, bowiem to oni będą pielęgnować lub nie dziedzictwo wcześniejszych gospodarzy miasta. Spuścizna po przedwojennych białostoczanach jest częścią historii współczesnych białostoczan. Jednak świadoma decyzja, jaką część tej spuścizny możemy uczynić własną historią, wymaga poznania tej historii. W dostępie do wiedzy na temat przeszłości miasta, w uwrażliwianiu na kontakt z ludźmi

37 Tamże, s. 18. 
$\mathrm{z}$ innych grup etnicznych, w uświadamianiu wartości własnej kultury oraz budzeniu świadomości własnej tożsamości - edukacja regionalna, obok rodziny, odgrywa wiodącą rolę.

Badania nad pamięcią przeszłości stają się niezbędne, szczególnie kiedy myślimy o regionie-pograniczu, który składa się z wielu przenikających się kultur. Praca nad pielęgnowaniem pamięci przeszłości wymaga zaprojektowania instytucjonalnych działań w tym zakresie. Nie można swobodnie poruszać się w teraźniejszości i budować mądrej przyszłości bez znajomości swojej przeszłości. Ważne jest poznanie przeszłości miejsc pochodzenia przodków, również przeszłości miejscowości, w której decydujemy się zamieszkać na stałe. Warto również ukłonić się w kierunku przeszłości w sytuacji, gdy korzystamy z gościnności danego miejsca jedynie w charakterze tymczasowych gości. Brak świadomości tożsamości własnej grupy etnicznej może powodować trudności w samookreśleniu się. Podobnie nieznajomość znaków miejsca, które się zamieszkuje, może powodować nieporozumienia komunikacyjne, sytuacje konfliktowe i idiosynkrazje. By temu zapobiec potrzebne są programy edukacyjne otwierające na przeszłość, jako swoisty pomost w kierunku uwrażliwiania na teraźniejszość. Badania nad pamięcią przeszłości są istotnym elementem sprzyjającym budowaniu teorii edukacji międzykulturowej i edukacji regionalnej jako subdyscyplin pedagogiki. Myślę, że dużą szansą dla współczesnej edukacji jest połączenie dwóch perspektyw: lokalnej i globalnej, między innymi po to, by społeczeństwa regionalne mogły bez lęku o utratę tożsamości otwierać się na nowości i zapożyczenia, przy jednoczesnej świadomości bogactwa własnej przeszłości - w przypadku Białegostoku wielokulturowej przeszłości.

\section{Bibliografia}

Assmann J.: Pamięć kulturowa. Pismo, zapamiętywanie i polityczna tożsamość w cywilizacjach starożytnych. Warszawa 2008, UW.

Barthes R.: System mody. Kraków 2005, UJ.

Barthes R.: Mitologie. Warszawa 2008, „Aletheia”.

Bokszański Z.: Tożsamości zbiorowe. Warszawa 2007, PWN.

Dobroński A.: Białystok - historia miasta. Białystok 1998, Zarząd Miasta Białegostoku. 
Griffin E. A.: Semiologia Rolanda Barthesa. W: E. A. Griffin: Podstawy komunikacji społecznej. Gdańsk 2003, GWP.

Halbwachs M.: Społeczne ramy pamięci. Warszawa 2008, Biblioteka Socjologiczna PWN.

Kwiatkowska H.: Czas, miejsce, przestrzeń - zaniedbane kategorie pedagogiczne. W: A. Nalaskowski, K. Rubacha (red.): Pedagogika u progu trzeciego tysiaclecia. Toruń 2001, UMK.

Milerski B., Śliwerski B. (red.): Leksykon PWN. Pedagogika. Warszawa 2000, PWN.

Nikitorowicz J.: Pogranicze, tożsamość, edukacja międzykulturowa. Białystok 2001, „Trans Humana”.

Nikitorowicz J.: Edukacja regionalna i międzykulturowa. Warszawa 2009, WAiP.

Petrykowski P.: Edukacja regionalna. Problemy podstawowe i otwarte. Torun 2003, UMK.

Sadowski A.: Białystok. Kapitał społeczny mieszkańców miasta. Białystok 2006, WSE.

Sobecki M.: Kultura symboliczna a tożsamość. Studium tożsamości kulturowej Polaków na Grodzieńszczyźnie z perspektywy edukacji międzykulturowej. Białystok 2007, „Trans Humana”.

Szpociński A. (red.): Wobec przeszłości, pamięć przeszłości jako element kultury wspótczesnej. Warszawa 2005, Instytut im. Adama Mickiewicza.

Szpociński A., Kwiatkowski P. T.: Przeszłość jako przedmiot przekazu. Warszawa 2006, PAN, „Scholar”.

Topolski J.: Założenia metodologiczne badań regionalnych $w$ zakresie historii. „Dzieje Najnowsze” 1973, nr 2.

Województwo białostockie. Warszawa 1927, GUS. Pierwszy Spis Ludności RP z 30 listopada $1921 \mathrm{r}$.

\section{Significance of regional education in commemorating the past - the case of multicultural Białystok}

\section{Summary}

In text I attempt to present the importance of regional education in cultivating past memory, using multicultural Bialystok as an example. I analyze the role of 
research on past memory in planning and implementing educational activities. I draw reader's attention to selected issues connected with past memory in the context of social research.

Translated by Joanna Sacharczuk 